\title{
A huge oceanic-type UHP metamorphic belt in southwestern Tianshan, China: Peak metamorphic age and $P-T$ path
}

\author{
ZHANG LiFei ${ }^{*}$, DU JinXue, LÜ Zeng, YANG Xin, GOU LongLong, XIA Bin, CHEN ZhenYu, \\ WEI ChunJing \& SONG ShuGuang
}

Key Laboratory of Orogenic Belts and Crustal Evolution, MOE, School of Earth and Space Sciences, Peking University, Beijing 100871, China

Received June 25, 2013; accepted July 26, 2013; published online August 26, 2013

\begin{abstract}
Recent progress in the study of the UHP metamorphic belt in southwestern Tianshan, China, is summarized in this paper. This about $80-\mathrm{km}$-long and over 10-km-wide UHP belt has been recognized by the discovery of coesite, coesite pseudomorphs and other UHP minerals. It is the largest oceanic-type UHP metamorphic belt reported so far. It has formed due to northward subduction of the Tianshan Paleo-Ocean. U-Pb dating of metamorphic rims of zircons from a coesite-bearing garnet-phengite schist yields a peak UHP metamorphic ages of 320 \pm 3.7 Ma. Combined with ages of 233-226 Ma obtained from rims of zircons from retrograded eclogites, a long retrograde metamorphic evolution $(>70 \mathrm{Ma})$ has been revealed. According to phase equilibria modeling, the $P-T$ paths of both coesite-bearing eclogites and garnet-phengite schists are characterized by thermal relaxation, i.e., the metamorphic temperature peak lags behind the pressure peak, indicating that the UHP rocks experienced slow and long heating and decompression during exhumation in the subduction channel. On the basis of the field observation that a small amount of eclogite lenses is wrapped in large volumes of metapelites, and the similar $P-T$ paths of both rock types, we propose that the exhumation of the UHP eclogites from southwestern Tianshan, China, may have resulted from the exhumation of large volumes of low-density metapelites, which carried the denser eclogites to the Earth's surface.
\end{abstract}

oceanic UHP metamorphic belt, coesite, peak metamorphic age, $P$ - $T$ path, southwestern Tianshan, China

Citation: $\quad$ Zhang L F, Du J X, Lü Z, et al. A huge oceanic-type UHP metamorphic belt in southwestern Tianshan, China: Peak metamorphic age and $P$ - $T$ path. Chin Sci Bull, 2013, 58: 4378-4383, doi: 10.1007/s11434-013-6074-x

Ever since the first prediction of ultrahigh-pressure (UHP) metamorphism of eclogites from Chinese southwestern Tianshan has been made by Zhang et al. $[1,2]$ on the basis of coesite pseudomorphs in garnet, quartz exsolution lamellae in omphacite and magnesite of metamorphic origin, it has been hotly debated, whether these rocks actually experienced UHP metamorphism [3,4]. Subsequently, decomposition textures of UHP carbonates [5] and relict coesite exsolution lamellae in omphacite [6] have been found in metapelites and eclogites. Recently, the discovery of wellpreserved coesite relicts in eclogites and metapelites hosting them from the Habutengsu and Atantayi Valleys [7-11] ended the controversy and irrefutably confirmed the existence of UHP metamorphism in the belt. This paper provides

*Corresponding author (email: Lfzhang@pku.edu.cn) a brief overview of important progress in the research on the Chinese southwestern Tianshan UHP metamorphic belt in recent years, and, furthermore, it elaborates the spatial distribution, the age of peak metamorphism and the $P-T$ path of the UHP metamorphic rocks to finally propose slow heating and decompression during the exhumation of the UHP eclogites.

\section{The spatial distribution of the ultrahigh- pressure metamorphic belt in Chinese south- western Tianshan}

The blueschist-eclogite belt is the main part of the Chinese southwestern Tianshan orogenic belt in central Asia formed by northward subduction of the Tarim plate underneath the 
Yili-Central Tianshan plate. The blueschist-eclogite belt is wedge-shaped, stretches NEE-SWW and the Chinese part is $\sim 200 \mathrm{~km}$ long. To the north, it is separated from the YiliCentral Tianshan plate by the South Tianshan Fault; to the south, it is fault juxtaposed against a unit of epi-metamorphic banded carbonate strata. The blueschist-eclogite belt consists of eclogites, blueschists, garnet-phengite schists, marbles and minor serpentinites. Among them, mica schists are the prevailing rock type; on a regional scale, they show largely varying pelitic, felsic, calcic and minor mafic bulk compositions. Eclogites and blueschists occur as blocks and lenses wrapped in these mica schists. Until now, UHP metamorphic minerals have been reported from an area covering $800 \mathrm{~km}^{2}$ in the northern part of Chinese southwestern Tianshan; in detail, these are: (1) inclusions of polycrystalline quartz aggregates in garnet surrounded by radial fractures being the first reported coesite pseudomorphs from Chinese southwestern Tianshan [1] (i in Figure 1); (2) relict coesite exsolution lamellae in porphyroblastic omphacite [6] (ii in Figure 1); (3) inclusions of coesite and its pseudomorphs in mica schists from the Habutengsu Valley [7,12] (iii in Figure 1); (4) coesite in eclogites from the
Habutengsu Valley [8] (iv in Figure 1); (5) coesite in both eclogites and mica schists from the lower reaches of the Atantayi Valley $[9,10]$ (v in Figure 1); (6) coesite in retrograded albite-mica schists from the upper reaches of the Atantayi Valley [9] (v in Figure 1); (7) coesite in garnet-phengite schists form the lower reaches of the Kebuerte Valley [11] (vi in Figure 1); and (8) decomposition textures of UHP carbonates in metapelites found at the foot of Mt. Muzhaerte [5] (vii in Figure 1).

Eclogites from Chinese southwestern Tianshan belong to the low-T lawsonite-bearing type that forms during cold subduction [17]. Although direct mineralogical and textural evidence for UHP metamorphism has been widely found, there is much less well-preserved coesite known from this region than from the medium-T UHP eclogites $\left(>600^{\circ} \mathrm{C}\right)$ of the Dabie-Sulu UHP belt, mainly, because very low-T eclogites contain a large amount of hydrous minerals, and the strong blueschist facies retrograde overprint makes the preservation of UHP minerals difficult $[13,14,18]$. On the basis of phase equilibria modeling, $P-T$ pseudosections were constructed for metapelites using garnets that have similar pelitic protoliths. Combining previous discoveries of coesite

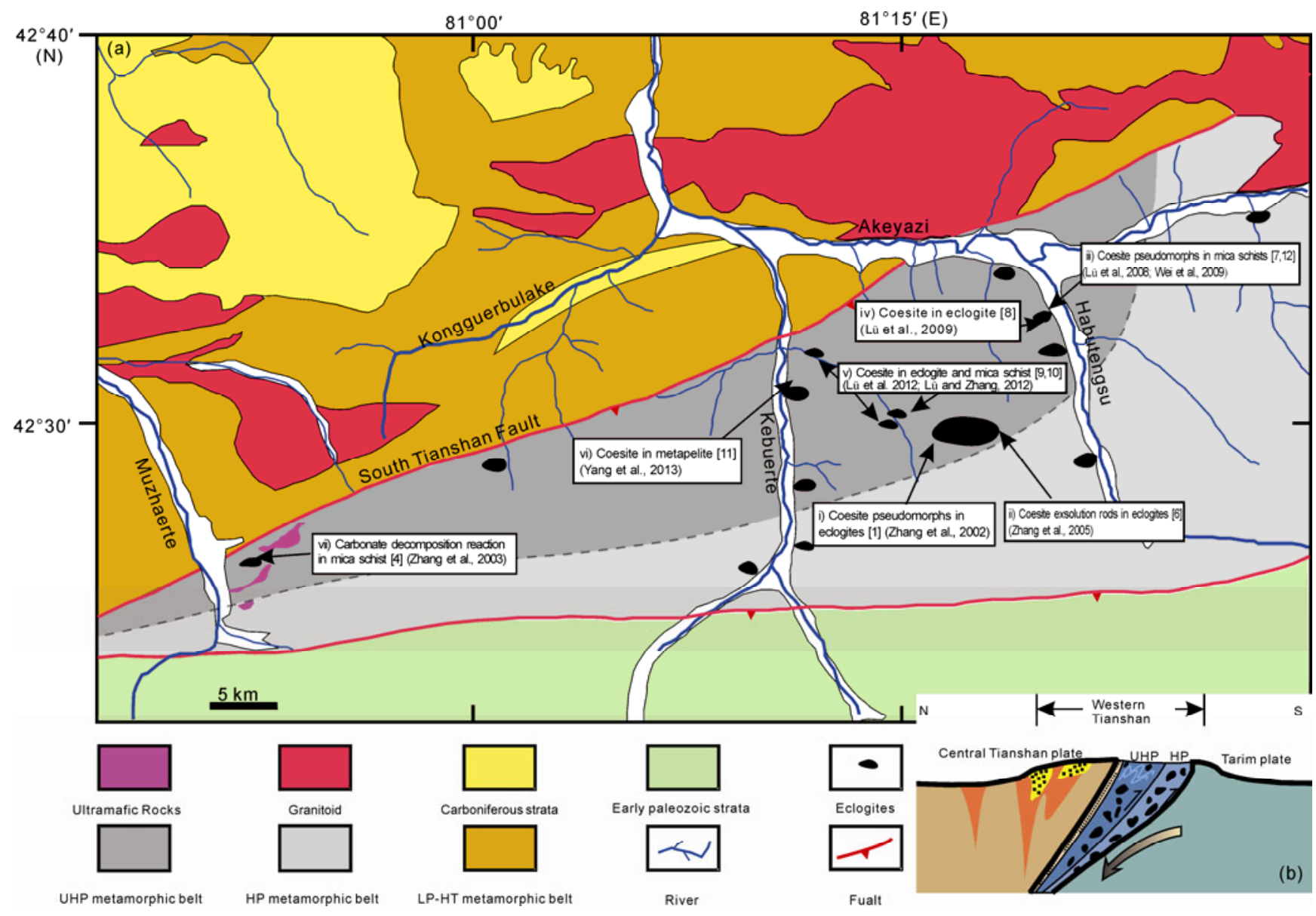

Figure 1 (a) The Chinese southwestern Tianshan UHP metamorphic belt; (b) schematic cross section of Chinese southwestern Tianshan showing the tectonic emplacement of exhumed slices from different depths as a result of the northward subduction of the Tianshan Paleo-Ocean underneath the Central Tianshan Plate (modified after [8,13-16]). 
and its pseudomorphs and taking the two sections of Habutengsu and Akeyazi as an example, a huge UHP belt nearly $80 \mathrm{~km}$ long and more than $10 \mathrm{~km}$ wide has been identified in the Chinese southwestern Tianshan blueschist-eclogite zone [9,15] (Figure 1). This UHP belt is three to four times as large as the earlier reported oceanic UHP belt in Zermatt-Saas, which is only $20 \mathrm{~km}$ long.

The Chinese southwestern Tianshan HP-UHP metamorphic belt is characterized by decreasing peak pressure conditions from north to south [15] and the occurrence of low-P and high-T metapelites to the north of the UHP belt, where metamorphic monazite from pelitic granulites yields a $\mathrm{U}-\mathrm{Th}-\mathrm{Pb}$ age of $280 \pm 8 \mathrm{Ma}$ [19]. Zircon U-Pb dating yielded ages of $333 \pm 3-326 \pm 3 \mathrm{Ma}, 293 \pm 3-294 \pm 2.2 \mathrm{Ma}$ and $266 \pm 13-$ $278 \pm 3 \mathrm{Ma}$ for syn-subduction, post-collisional and S-type granitoids, respectively [20]. Based on the data mentioned above, the tectonic model proposed by Zhang [14], that the Chinese southwestern Tianshan UHP metamorphic belt hosts a paired metamorphic belt formed by northward subduction of the Tianshan Paleo-Ocean underneath the Yili-Central
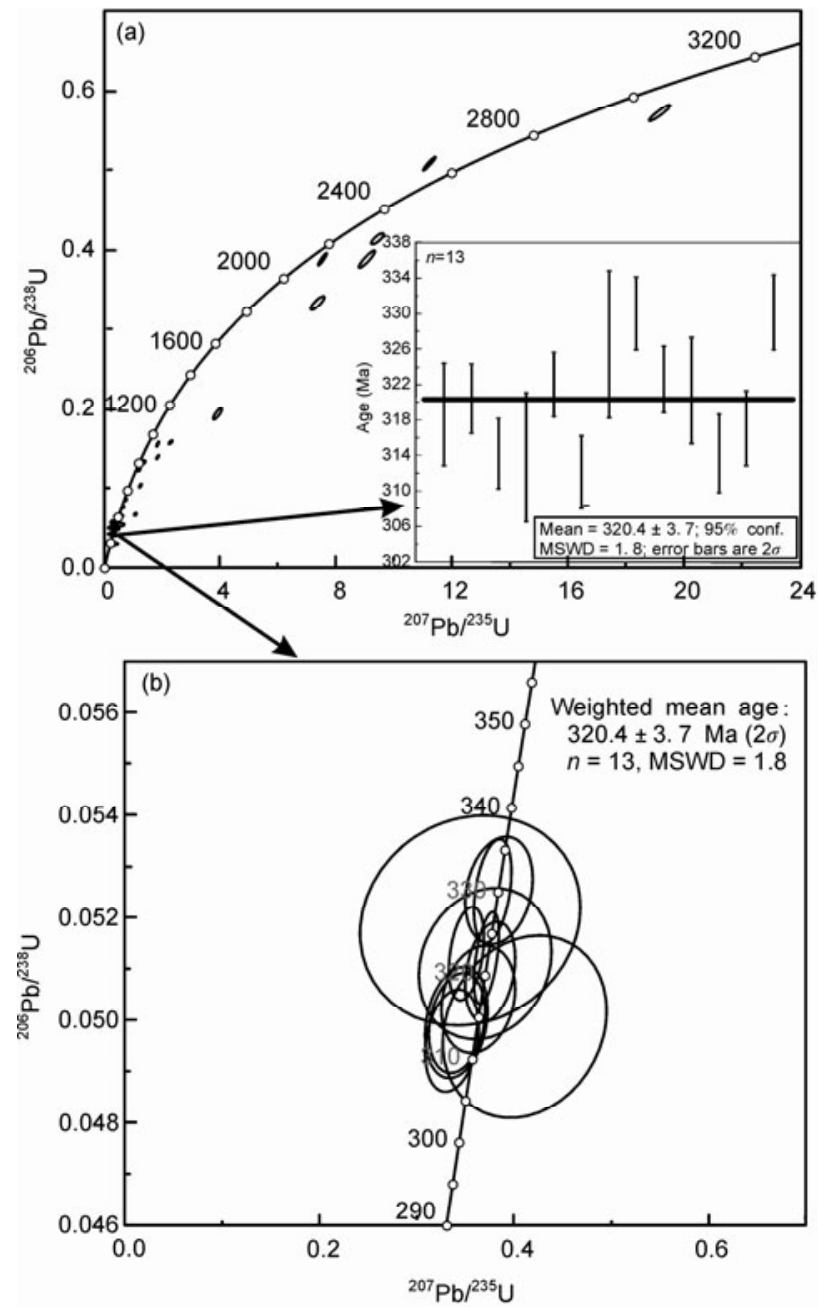

Tianshan plate, is confirmed again [14,15] (Figure 1(b)).

\section{The timing of UHP peak-metamorphism}

Zircons from a coesite-bearing garnet-phengite schist (garnet 10 vol. $\%$, phengite 35 vol. $\%$, quartz 43 vol. $\%$, chlorite 5 vol.\%, paragonite $3 \mathrm{vol} \%$, albite 2 vol.\% and zoisite 1 vol.\%) have metamorphic rims (Figure 2(c)). Out of these rims, 13 have been analyzed and yielded a weighted mean age of $320 \pm 3.7 \mathrm{Ma}$ (Figure 2(a),(b)) [11]. Though no coesite inclusions were identified in these zircon rims, phengite and rutile commonly do occur as inclusions in them, and, furthermore, phase equilibria modeling of this coesite-bearing garnet-phengite schist yields peak metamorphic $P$ - $T$ conditions of $565^{\circ} \mathrm{C}$ and $29 \mathrm{kbar}$ [11]. Therefore, the age of $320 \pm 3.7 \mathrm{Ma}$ should be considered as the age of peak metamorphism, in consistency with a garnet-omphacite-whole rock Lu-Hf isochron age of $326.9 \pm 1.3 \mathrm{Ma}$ of an UHP eclogite [21]. Nevertheless, the peak metamorphic age of the
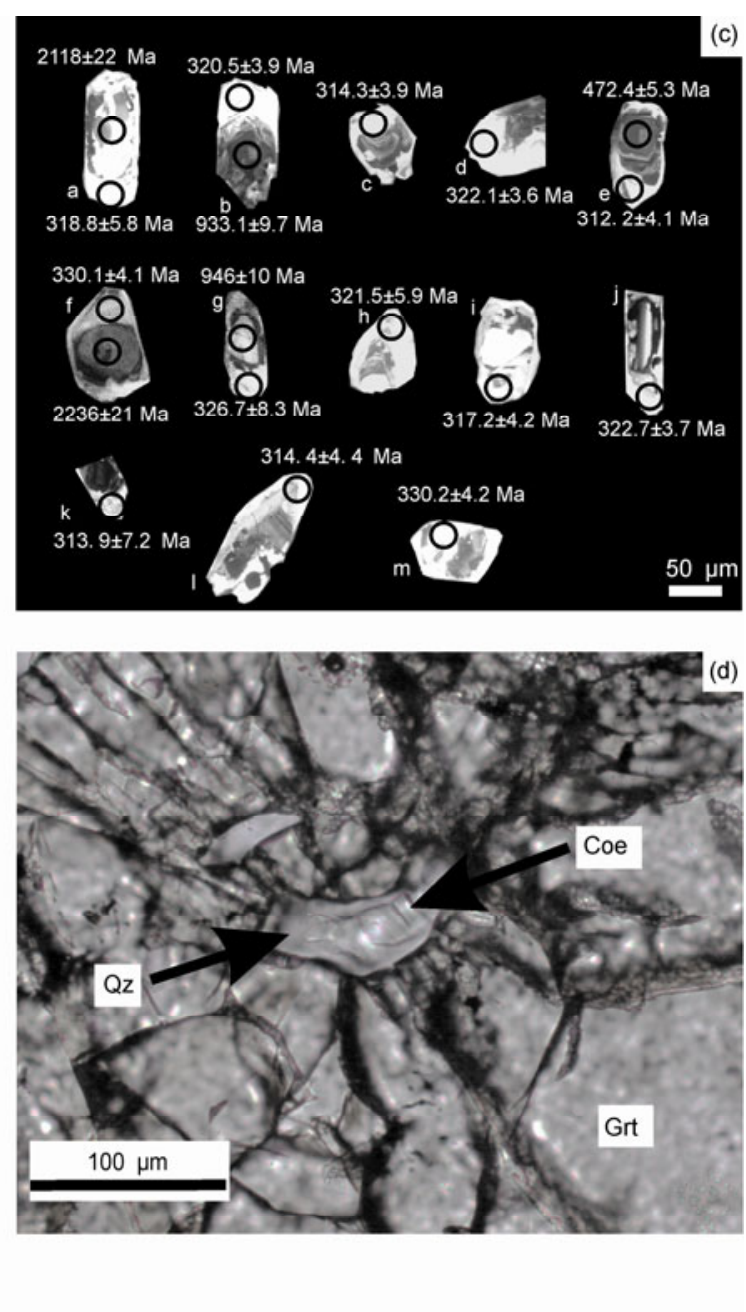

Figure 2 (a) Zircon U-Pb concordia diagram for the investigated coesite-bearing metapelite; (b) weighted mean diagram; (c) CL images of zircon crystals; (d) a well-preserved coesite inclusion in garnet (modified after [11]). 
UHP eclogites from Chinese southwestern Tianshan is still hotly debated. Several methods such as Ar/Ar dating, $\mathrm{Sm}-\mathrm{Nd}, \mathrm{Rb}-\mathrm{Sr}$ and Lu-Hf isochron dating, and in situ U-Pb dating of zircon and rutile, have widely been applied and suggested a broad range of metamorphic ages from 415 to

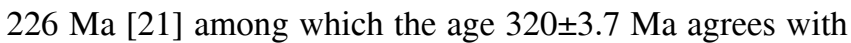
the recently published range of 320 to $310 \mathrm{Ma}$ [22-24].

\section{$3 \quad P$-T path of the UHP metamorphic rocks}

The $P$ - $T$ path of UHP metamorphic rocks can be considered as "black box" of an orogenic belt reflecting the course of subduction and collision and it is therefore a key aspect for research addressing the tectonic evolution of orogenic belts.
Early petrological studies proposed that $P-T$ paths of eclogites from Chinese southwestern Tianshan are hairpin-like $[1,25,26]$, i.e. metamorphic temperature and pressure reach their peaks simultaneously, and decompression during exhumation was accompanied by cooling. Well-preserved coesite inclusions in the mantle rather than the rim of porphyroblastic garnet with prograde compositional zoning discovered in recent years implies that the $P$ maximum of the $P-T$ path has been reached earlier than the $T$ maximum (Figure 3(a),(b)) [7,8]. Based on detailed phase equilibria modeling of a coesite-bearing eclogite, Lü et al. [8] proposed that its $P-T$ path is characterized by thermal relaxation, i.e., coesite formed at the peak pressure after rapid subduction, and the peak temperature was subsequently reached during exhumation (Figure 3(e),(f)). Furthermore,
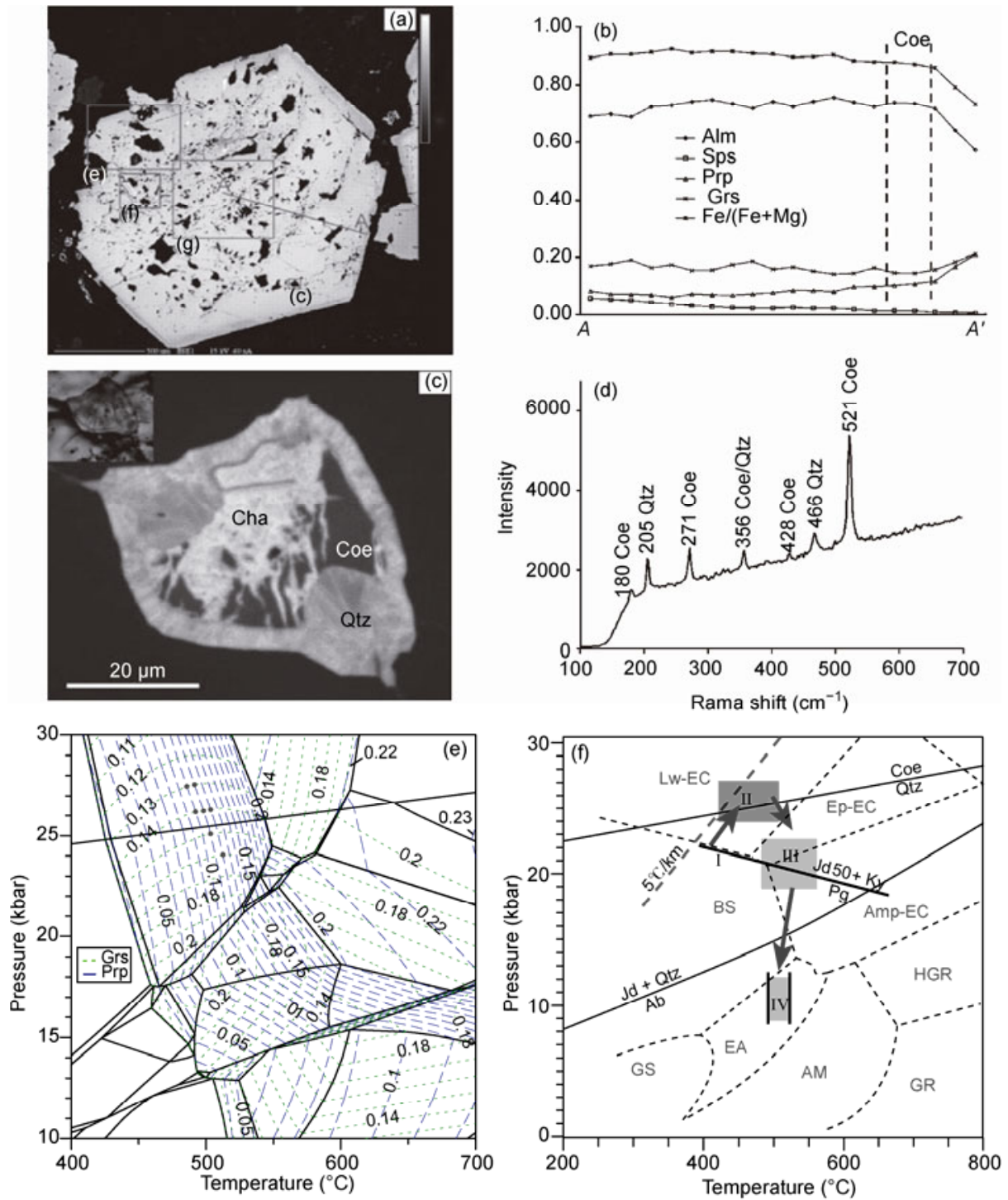

Figure 3 Petrology and metamorphic evolution of the coesite-bearing eclogite from Chinese southwestern Tianshan (modified after [8]). (a) Coesite-bearing garnet, where coesite inclusions appeared in the mantle; (b) compositional profile of the coesite-bearing garnet shown in (a); (c) inclusions of coesite in garnet shown in (a); (d) Raman spectra of coesite shown in (c); (e) $P-T$ pseudosection for the coesite-bearing eclogite; (f) $P$ - $T$ path of the coesite-bearing eclogite characterized by thermal relaxation. Coesite grew at peak- $P$ conditions at $\sim 450^{\circ} \mathrm{C}$ (stage II: peak coesite eclogite facies), than $T$ increases to $\sim 550^{\circ} \mathrm{C}$ at $20 \mathrm{kbar}$ (stage III: retrograde quartz eclogite facies) and finally decreases to $500^{\circ} \mathrm{C}$ at $10 \mathrm{kbar}$ (stage IV: epidote amphibolite facies) during retrograde metamorphism. 


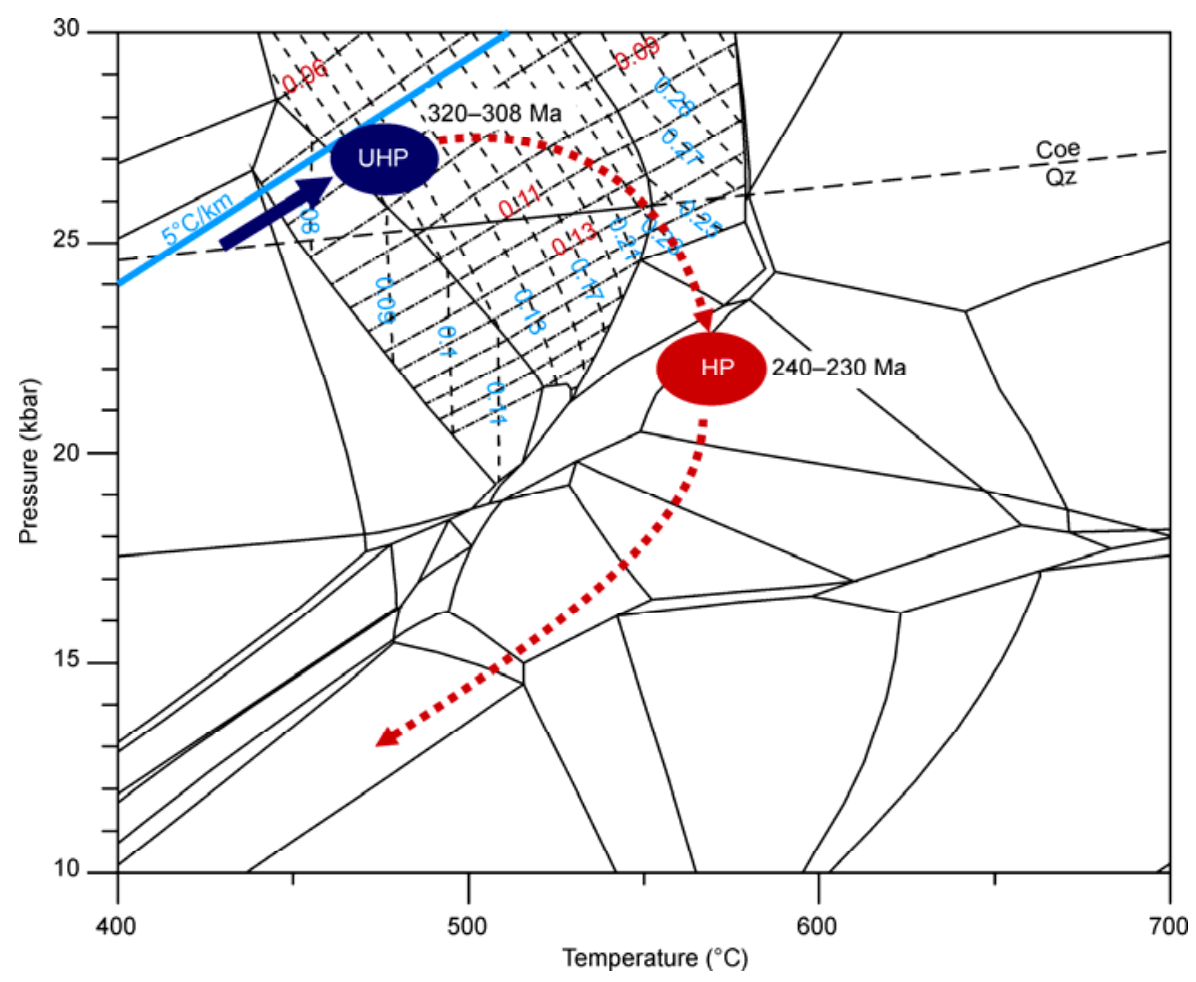

Figure $4 P$-T-t path of the UHP metamorphic belt in Chinese southwestern Tianshan.

Wei et al. [12] obtained a similar $P-T$ path for a coesite pseudomorph-bearing metapelite that underwent similar thermal relaxation. These thermal relaxation $P-T$ paths indicate that the UHP eclogites and a portion of the metapelites from Chinese southwestern Tianshan experienced slow exhumation over a long time period. The exhumation rate is lower than that of thermal relaxation of the hanging-wall plate, which is in accordance with the long period of retrograde metamorphism from 320 to $240 \mathrm{Ma}$ (Figure 4). The slow decompression and the long duration of the exhumation as well as the thermal relaxation $P-T$ path is in sharp contrast to typical continental UHP metamorphic belts such as the Dabie-Sulu UHP metamorphic belt, which might be explained by the fact that oceanic UHP rocks have higher densities than continental ones. This might also explain, why there are fewer oceanic UHP metamorphic belts than continental ones, because it makes the exhumation of UHP oceanic rocks to the Earth's surface more difficult. Moreover, UHP eclogites and metapelites show similar $P-T$ paths characterized by thermal relaxation suggesting that the exhumation of the UHP eclogites in Chinese southwestern Tianshan has been controlled by buoyancy and that the eclogites were dragged up to the surface by the surrounding metapelitic hosts having a much lower density $[7,8,12,27]$.

\section{Conclusions}

The Chinese southwestern Tianshan UHP metamorphic belt is currently the largest oceanic-type UHP metamorphic belt in the world. It extends nearly $80 \mathrm{~km}$ from east to west and is over $10 \mathrm{~km}$ wide. The age of UHP peak-metamorphism is $320 \pm 3.7 \mathrm{Ma}$, and the $P-T$ path is characterized by thermal relaxation, i.e. the metamorphic temperature peak lags behind the pressure peak. Temperature increases by $\sim 100^{\circ} \mathrm{C}$ during exhumation. Zircon U-Pb dating shows that retrograde metamorphism lasted $\sim 60-80 \mathrm{Ma}$. Both UHP eclogites and metapelites show similar $P-T$ paths with thermal relaxation, indicating that the exhumation of the Chinese southwestern Tianshan UHP metamorphic belt is consistent with a buoyancy-driven model according to which the exhumation of low density metapelites can carry denser eclogites to the Earth's surface.

We thank Prof. Zheng Yongfei for his invitation. This work was supported by the National Basic Research Program of China (2009CB825007) and the National Natural Science Foundation of China (41121062 and 41272069).

1 Zhang L F, Ellis D J, Jiang W B. Ultrahigh-pressure metamorphism in western Tianshan, China: Part I. Evidence from inclusions of coesite pseudomorphs in garnet and from quartz exsolution lamellae in omphacite in eclogites. Am Mineral, 2002, 87: 853-860

2 Zhang L F, Ellis D J, Williams S, et al. Ultra-high pressure metamorphism in western Tianshan, China: Part II. Evidence from magnesite in eclogite. Am Mineral, 2002, 87: 861-866

3 Klemd R. Ultrahigh-pressure metamorphism in eclogites from the western Tianshan high-pressure belt (Xinjiang, western China)Comment. Am Mineral, 2003, 88: 1153-1156 
4 Zhang L F, Ellis D, Williams S, et al. Ultrahigh-pressure metamorphism in eclogites from the western Tianshan, China-Reply. Am Mineral, 2003, 88: 1157-1160

5 Zhang L F, Ellis D J, Arculus R J, et al. 'Forbidden zone' subduction of sediments to $150 \mathrm{~km}$ depth-The reaction of dolomite to magnesite plus aragonite in the UHPM metapelites from western Tianshan, China. J Metamorph Geol, 2003, 21: 523-529

6 Zhang L F, Song S G, Liou J G, et al. Relict coesite exsolution in omphacite from Western Tianshan eclogites, China. Am Mineral, 2005, 90: 181-186

7 Lü Z, Zhang L F, Du J X, et al. Coesite inclusions in garnet from eclogitic rocks in western Tianshan, northwest China: Convincing proof of UHP metamorphism. Am Mineral, 2008, 93: 1845-1850

8 Lü Z, Zhang L F, Du J X, et al. Petrology of coesite-bearing eclogite from Habutengsu Valley, western Tianshan, NW China and its tectonometamorphic implication. J Metamorph Geol, 2009, 27: 773-787

9 Lü Z, Zhang L F. Coesite in the eclogite and schist of the Atantayi Valley, southwestern Tianshan, China. Chin Sci Bull, 2012, 57: 1467-1472

10 Lü Z, Zhang L F, Du J X, et al. Petrology of HP metamorphic veins in coesite-bearing eclogite from western Tianshan, China: Fluid processes and elemental mobility during exhumation in a cold subduction zone. Lithos, 2012, 136: 168-186

11 Yang X, Zhang L, Tian Z, et al. Petrology and U-Pb zircon dating of coesite-bearing metapelite from the Kebuerte Valley, western Tianshan, China. J Asian Earth Sci, 2013, 70-71: 295-307

12 Wei C J, Wang W, Clarke G L, et al. Metamorphism of high/ultrahighpressure pelitic-felsic schist in the South Tianshan Orogen, NW China: Phase Equilibria and $P-T$ Path. J Petrol, 2009, 50: 1973-1991

13 Zhang L, Ai Y, Li Q, et al. The formation and tectonic evolution of UHP metamorphic belt in southwestern Tianshan, Xinjiang (in Chinese). Acta Petrol Sin, 2005, 21: 1029-1038

14 Zhang L F, Ai Y L, Song S G, et al. A brief review of UHP meta-ophiolitic rocks, southwestern Tianshan, western China. Int Geol Rev, 2007, 49: 811-823

15 Lü Z, Bucher K, Zhang L, et al. The Habutengsu metapelites and metagreywackes in western Tianshan, China: Metamorphic evolution and tectonic implications. J Metamorph Geol, 2012, 30: 907-926

16 Zhang L F, Ai Y L, Li X P, et al. Triassic collision of western Tianshan orogenic belt, China: Evidence from SHRIMP U-Pb dating of zircon from HP/UHP eclogitic rocks. Lithos, 2007, 96: 266-280

17 Du J X, Zhang L F, Lu Z, et al. Lawsonite-bearing chloritoidglaucophane schist from SW Tianshan, China: Phase equilibria and $P-T$ path. J Asian Earth Sci, 2011, 42: 684-693

18 Zhang L F, Lü Z, Zhang G B, et al. The geological characteristics of oceanic-type UHP metamorphic belts and their tectonic implications: Case studies from Southwest Tianshan and North Qaidam in NW China. Chin Sci Bull, 2008, 53: 3120-3130

19 Gou L, Zhang L. Petrology and U-Th-Pb chemical monazite dating of the low-P metapelitic granulites at the region of Muzhaerte River in southwestern Tianshan, NW China, and their geological implications. Acta Petrol Sin, 2009, 25: 2271-2280

20 Gou L L, Zhang L F, Tao R B, et al. A geochemical study of synsubduction and post-collisional granitoids at Muzhaerte River in the Southwest Tianshan UHP belt, NW China. Lithos, 2012, 136: 201224

21 Zhang L F, Du J X, Shen X J. The timing of UHP-HP eclogitic rocks in Western Tianshan, NW China: The new SIMS U-Pb zircon dating, $\mathrm{Lu} / \mathrm{Hf}$ and $\mathrm{Sm} / \mathrm{Nd}$ isochron ages. Abstracts of the 8th International Eclogite Conference. Xining, 2009

$22 \mathrm{Su} \mathrm{W}$, Gao J, Klemd R, et al. U-Pb zircon geochronology of Tianshan eclogites in NW China: Implication for the collision between the Yili and Tarim blocks of the southwestern Altaids. Eur J Mineral, 2010, 22: 473-478

23 Li Q L, Lin W, Su W, et al. SIMS U-Pb rutile age of low-temperature eclogites from southwestern Chinese Tianshan, NW China. Lithos, 2011, 122: 76-86

24 Klemd R, John T, Scherer E E, et al. Changes in dip of subducted slabs at depth: Petrological and geochronological evidence from HPUHP rocks (Tianshan, NW-China). Earth Planet Sci Lett, 2011, 310: 9-20

25 Gao J, Klemd R, Zhang L F, et al. P-T path of high-pressure/lowtemperature rocks and tectonic implications in the western Tianshan Mountains, NW China. J Metamorph Geol, 1999, 17: 621-636

26 Zhang L F, Gao J, Ekebair S, et al. Low temperature eclogite facies metamorphism in Western Tianshan, Xinjiang. Sci China Ser D-Earth Sci, 2001, 44: 85-96

27 Tian Z L, Wei C J. Metamorphism of ultrahigh-pressure eclogites from the Kebuerte Valley, South Tianshan, NW China: Phase equilibria and $P$-T path. J Metamorph Geol, 2013, 31: 281-300

Open Access This article is distributed under the terms of the Creative Commons Attribution License which permits any use, distribution, and reproduction in any medium, provided the original author(s) and source are credited. 